\title{
The Shemita Effect, How a Jewish agricultural law prompted fear for Evangelical investors: Confirmation Bias and Bandwagoning in Action
}

\author{
Daria J. Newfeld \\ Albright College, USA \\ dnewfeld@albright.edu
}

\begin{abstract}
This paper examines how Shemita, a Jewish agricultural law only applicable in Israel came to be viewed by Evangelical Christian Investors as a signal of a potential stock market crash in September, 2015 purportedly as a consequence of G-d's displeasure with the United States. In 2014 Johnathan Cahn, a popular Evangelical preacher, published "The Shemita Effect" which claimed that the seven year Shemita cycle mirrored stock market patterns over the last 50 years and suggested an impending crash. This theory was quickly taken up by conservative Christian Evangelical media and at least one man was convinced enough to start an entire investment company based on it despite the fact that it is easily disproven using basic statistical analysis of freely available data. This bizarre incident illustrates confirmation bias and bandwagoning effects in action, amplified with religious fervor.
\end{abstract}

Keywords: Behavioral Finance, Religion, Confirmation Bias, Bandwagoning, Convergence

\section{Introduction}

What is Shemita? Literally translated Shemita means "to release." According to Jewish tradition the Shemita year is the seventh year in a seven year cycle. Jewish law states that during this year the land may not be farmed and any produce which does sprout is considered ownerless and cannot be harvested for commercial gain because essentially the land is "released" from ownership for that year. Similarly, all personal debts should be cancelled or "released". The Biblical impetus for these laws can be found in three passages:

"Six years shall you sow your land and gather in your yield; but in the seventh year you shall let it rest and lie fallow." Exodus 23

"For six years you shall sow your field, and for six years you shall prune your vineyard, and gather in its produce. But in the seventh year, the land shall have a complete rest, a Sabbath to the L-rd; you shall not sow your field, you shall not prune your vineyard, nor shall you reap the after-growth of your harvest... And [the produce of] the Sabbath of the land shall be yours to eat for you, for your male and female servants, and for your hired worker and resident who live with you." Leviticus 25:3-6

"At the end of seven years you will make a release. And this is the manner of the release: to release the hand of every creditor from what he lent his friend; he shall not extract from his friend or his brother, because the time of release for the L-rd has arrived." Deuteronomy 15:1-2

All sources seem to agree that the agricultural aspects of these laws only apply in Israel and even then there are "work- arounds" that can be employed (Krakowski, 2014). Matza Menutak, literally, "detached platform" allows the use of hydroponics as a growing technique because the plants are not attached to the soil (Krakowski, 2014). Alternatively the produce may be collected and then distributed thru a Otzar Beit Din system whereby the farmers are hired by the collective to tend and harvest the crops from their own "released" land which is then distributed to members of the collective (Krakowski, 2014). The most controversial approach, Heter Mechirah, temporarily sells land owned by a Jew to a non-Jew for the Shemita year, in this way the original Jewish owner of the land may continue to farm and harvest the land without violating the law Schwartz (2014). The loan forgiveness aspect is also virtually a moot point today. A Pruzbul is a legal document that transfers ownership of the debt from the creditor to the Beit Din (Jewish court) who is not obligated to nullify the debt during the Shemita year (Ohrenstein, 1998). While all of this may be interesting, it is hardly the stuff of best sellers or viral YouTube videos and yet between 2012 and 2015, that is exactly what Shemita became, especially among Evangelical Christians. The Google Trends search score of "Shemitah" is 100 meaning that more than $10 \%$ of searches were for this word! This essay will examine how a Jewish law seemingly pertaining only to Orthodox Jews farming or purchasing produce in the tiny country of Israel spurred best-selling books, newspaper articles, television interviews and internet videos in the United States aimed almost exclusively at a non-Jewish audience. 
Who are Evangelical Christians? The Oxford English dictionary defines Evangelical Christianity as transdenominational movement within Protestant Christianity, focusing on the doctrine of salvation by grace through faith in Jesus Christ's atonement. The movement has a long history of political involvement and economic discourse based around the idea that America is a land of spiritual exceptionalism ordained by G-d for greatness (Hunter, 1991; Skillen, 2004). The idea that negative economic events arise as a consequence of the loss of G-d's favor seems to stem naturally from this view point. For example, the Evangelical magazine Journal-Champion once ran an article stating, "Because of sin, God usually spanks his people in the pocketbook - farmers get hit in their crops, other Americans get hit in the paycheck" (Phillips-Fein, 2009; Martin, 2013). It is also important to note that Evangelical sermons often stress sound financial decision making and note that there is no contradiction between "seeking wealth and seeking godliness" (Martin, 2013). In fact, as early as 1905 the Protestant faith, specifically the Protestant work ethic was argued to have a positive impact on economic growth (Weber, 1905).

How did Evangelicalshear about Shemita? Jonathan Cahn, a messianic preacher and author of the 2014 book and corresponding DVD, "The Mystery of Shemita," argues that Shemita is the key to understanding geopolitical and economic fluctuations because God either punishes or rewards a nation on this cycle. In 2015the text is the number 1 best seller in Amazon's Christian Proficiencies section. It has also appeared on the New York Times' Best Seller List and USA Today's Best-Selling Books Top 150 list. According to Cahn's hypothesis, God's reaction will be particularly pronounced towards the end of the Shemita year because that is the time when the Israelites were required to cancel their debts. Cahn explained his hypothesis in an interview on the Christian Broadcast Network's The 700 club on 9/8/15:

"The Shemita is an extraordinary thing... all debts are wiped clean, credits are wiped clean, financial accounts of the nation are wiped clean and this is to be a blessing pact but what happens when Israel turns away from God, the blessing turns into a sign of judgment. ...The amazing thing is if you look at the last 50 years: 1966-a year of Shemita, the stock market collapses, 1973- a year of the Shemita the stock market collapses. 1980 you have recession and then the stock market collapses after. You have 1987; the stock market collapses in the Shemita of that and you have Black Monday, the worst percent crash in history. Shemita of 1994 the bond market collapses [it is] called the bond market massacre [the] greatest in history. 2001, you have the stock market collapsing, recession, you have the greatest point crash in history and you have 9/11!...And then you have 2008 which is the last one and what do we have? - The greatest collapse since the great depression." (Robertson, 2015)

Articles citing Cahn's theory and it's predations for the end of the 2015 Shemita cycle appeared on several news sites geared towards Evangelical Christians as well as the general public. The Evangelical sites included: the Charisma News (Snyder, 2015), CBN News (Stahl, 2015) and Prophecy News Watch (Hohmann, 2015). Articles citing Cahn's work also appeared in the Huffington Post (Schwimmer, 2015) and the World Tribune. The British investment website MarketOracel ran an article purportedly documenting the cyclical trend (Carlson, 2015). The Times of India even ran an article linking its own "Black Monday" to the Shemita cycle (Sinha, 2015). Jeff Berwick, presented similar linkages in his viral YouTube video "SHEMITAH EXPOSED: Financial Crisis Planned for September 2015," which at the time of this draft has close to 2 million views; however, his presentation lacked the religious connotation expressed by Cahn.

"Regarding Shemita, I want to state for the record that my discovery of it has emerged as part of my financial analysis. The Shemita has religious connotation but that's not my focus. The point is that there are evidence based ramifications to Shemita and from a practical standpoint, that's what I wish to investigate and address... What caught my attention was for the last day of the Shemita for the last two Shemitas in 2001 and 2008; fell on days with a major market collapse. The last day of Shemita in 2001 fell on 9/17 and that was the first day U.S. stock markets opened after 9/11. That day had the greatest one day stock market point crash in U.S. history up to that time. The Dow fell almost 700 points or $7 \%$ and it was a record that held for precisely 7 years until the end of the next Shemita year, that year was 2008. On 9/28/08, the exact final day of the Shemita, the Dow plummeted 777 points which still today remains the greatest one day stock market crash of all time" (Berwick, 2014)

Berwick's video claims to have traced the Shemita cycle beginning in 1907 and noted it's linkages with stock market declines in 1907 and 1931, WWII's beginning and end, the end of the Bretton Woods system 1973 and 
1987's "Black Monday" (Berwick, 2014). The video concludes with the suggestion that investors can learn how to weather similar market conditions in September 2015 by purchasing his monthly newsletter for $\$ 39.99$ (Berwick, 2014). Breaking Israel News, an online newspaper geared towards Evangelical Christians and Zionistic Jews, reported that, "an ANOVA test [revealed] that there was some basis for the financial advisor's strategy of avoiding investing in years that ended in seven. It gave a statistical advantage of 100 base points, with years not ending in seven averaging an annual return of 10.19 percent, compared to an overall average of 9.04 percent." (Berkowitz, 2015) This analysis was attributed to Thomas Pound, High School math teacher, although no such analysis is available online or in any scholarly publication. The same story also appeared on World News Daily another online newspaper.

One is unable to determine how many investment decisions were made based on the assumption of an impending stock market crash in the fall of 2015 but it is known that at least 1 investment advisory company, "Shemitah Investment Advisors LLC," was specifically set up to employ market timing techniques based on that assumption. The firm's investment strategy explicitly states, "We will go "short" (bet against) the stock market in the summer of 2015, in the form of inverse ETFs, traditional shorts, and various put options depending on risk tolerance.... When the "short" positions are sold, likely in October, and hopefully after a crash in gold \& silver prices, we will enter into a gold \& silver mining investment, in the form of ETFs or individual stocks \& warrants, depending on risk tolerance... This gold \& silver mining position will also be short term, as we believe that the political risk of gold legislation will increase rapidly in 2016. Therefore, the overall timeframe of this investing strategy is from the summer of 2015 until roughly the summer of 2016" (Hirelman, 2015). At the time of this draft, the 5575 Shemita year (roughly 9/2014-9/2015 in the Gregorian Calendar) has concluded without a dramatic market decline. While the Shemita cycle supporters either back pedal or move onto the next prophecy this essay will highlight the flaws of Cahn and his contemporary's analysis as well investigate how this phenomena came about thru the lens of behavioral finance.

\section{An Empirical analysis of "the Shemita Effect"}

Zenz (2015) presents an empirical analysis of Cahn's claims which outlines how the correlations discussed fail to adequately support a causal link due to their lack of consistency. While he did find statistically significant changes in the value of the Dow Jones Industrial Average for Shemita vs. non-Shemita months, the explanatory power was extremely low. Furthermore, he found no statistically significant difference in U.S. GDP change in Shemita years vs. Non-Shemita years between 1889 and 2008 using either annual or quarterly data. In order to more fully investigate the potential "Shemita effect" one should compare the monthly returns of broad market indices during Shemita periods compared with those immediately preceding and following the Shemita. Two indices will be considered, the Wilshire 5000 Total Market Index and the Russell 3000 Index. These indices are chosen because they arguably provide the most comprehensive picture of the U.S. market at any point in time.

The Wilshire 5000 Total Market Indexis a market-capitalization-weighted index of the market value of all stocks actively traded in the United States. At its inception there were 5000 stocks included, since that time the number has varied from a high of 7,562 on July 31, 1998 to a low of 3,776 as on December 31, 2013, currently 3,691 companies are included (Wilshire 5000 fact sheet). Monthly average, non-seasonally adjusted data was downloaded from the Federal Reserve Economic Database (FRED). Based on data availability the Shemita years of 1973, 1980, 1987, 1994, 2001 and 2008 are examined. Since the Jewish and Gregorian calendars do not match up perfectly, the Shemita period is defined for test purposes as September-November of the Shemita year. Both two-tailed t-tests and ANOVA analysis of the Shemita months compared with both the months immediately before and after the Shemita period reveal no statistically significant differences. For consistency the "Pre-Shemita" and "Post-Shemita" periods are defined as June-August and DecemberFebruary of the Shemita and following years. Furthermore, there was no statistically significant difference between the index values in all of the Shemita months compared with all of the remaining months using either the two-tailed t-tests or ANOVA analysis.

According to the Russell 3000 fact sheet, "the Russell 3000 Index measures the performance of the largest 3,000 U.S. companies representing approximately $98 \%$ of the investable U.S. equity market." The index was developed with a base value of 140.00 on December 31, 1986. Monthly adjusted closing data was downloaded 
from Yahoo finance from September 1, 1987 to October 1, 2015. Based on data availability the Shemita years of 1987, 1994, 2001 and 2008 are examined. The "Pre-Shemita" and "Post-Shemita" periods are as defines above. Consistent with Wilshire 5000 results there are statistically significant differences between the Shemita months and non-Shemita months no matter how you parse the data. The combined results from both indices are shown below.

Table 1: significant differences between the Shemita months and non-Shemita month's data

\begin{tabular}{lllll} 
& \multicolumn{2}{l}{ Wilshire $\mathbf{5 0 0 0}$ Total Market Index } & \multicolumn{2}{l}{ Russell 3000 Index } \\
& T-test & Anova & T-test & Anova \\
\hline Shemita vs. Non Entire data set & 0.379435195 & 0.400888839 & 0.631497996 & 0.356213 \\
Shemita vs. Pre-Shemita & 0.286427419 & 0.294587717 & 0.188817114 & 0.130344 \\
Shemita vs. Post-Shemita & 0.861078577 & 0.456181898 & 0.235689462 & 0.252659 \\
Shemita vs. Pre \& Post & .201954097 & 0.575966363 & 0.712678273 & 0.710245 \\
\hline
\end{tabular}

As these results show, the invalidity of the "Shemita effect" can be quickly documented using freely available data and simple statistical analysis preformed on Excel, so why did it persist? The next segment will examine the behavioral heuristics exhibited by the Evangelical Christian investors and postulate why they may have been particularly susceptible to them.

\section{Literature Review}

A Review of the Behavioral Heuristics Exhibited: Behavioral finance is an ever evolving interdisciplinary field synthesizing research from finance, economics, psychology and neurology to examine how individuals make financial decisions and how those decisions impact the market as a whole. Recent research has shown that the same areas of the brain that generate emotional states also process information about risk and rewards suggesting that emotions influence financial decisions. Kuhnen and Knutson (2011) find that excitement induces risk taking and confidence in one's ability to evaluate investment alternatives. Conversely, they find that negative emotions such as anxiety have the opposite effects, thus they note that investors attempt to maintain a positive emotional state by ignoring contradictory information. This tendency underlies the basic behavioral heuristics that are exemplified by the Evangelical response to "the Shemita effect."

Confirmation bias: "A mind is a terrible thing to change. You decide gold is a good bet to hedge against inflation, and suddenly the news seems to be teeming with signs of a falling dollar and rising prices down the road. Or you believe stocks are going to outperform other assets, and all you can hear are warnings of the bloodbath to come in the bond and commodity markets. In short, your own mind acts like a compulsive yesman who echoes whatever you want to believe. Psychologists call this mental gremlin the "confirmation bias"" (Jason Zweig, in the Wall Street Journal, November 19, 2009). The confirmation bias is the tendency for a person to place more weight on new information that supports their initial opinion and less weight on new information that runs contrary to it, thereby artificially subconsciously confirming their original opinions. This bias has been extensively studied beginning with Lord et al. (1979). Their study examined subjects' reactions to capital punishment. Subjects were presented with some evidence showing that the threat of capital punishment was an effective crime deterrent, and some suggesting that it was not. They found that both initial proponents and opponents to capital punishment tended to rate the evidence that was in line with their initial opinion as being more convincing and reliable and that their opinions after reading this mixed evidence were strengthened in the direction of their initial opinion, which is at odds with Bayesian theory. (Lord et al., 1979) Similarly, Darley and Gross (1983) find that subjects who are primed with a good initial opinion end up with an even more positive evaluation after viewing mixed evidence and vice versa.

Hart et al. (2009) present the most comprehensive synthesis of the literature in this area to date. Their metaanalysis examined 91 studies encompassing 8,000 participants. Their findings indicate that people are twice as likely to pay attention to information that is in line with their prior beliefs. They also note that confirmation bias is strongest when:

- the information received are of good quality 
- the decision maker has a high commitment towards his prior beliefs (i.e. their religion lends credence to the idea)

- decision maker is less confident

- the subject is "closed-minded"

Consistent with this literature, the evidence of "the Shemita Effect" must have appeared to be everywhere for Evangelical Christians because, as documented above, it appeared on several media sites targeted towards the group thus perpetuating itself by generating further searches. Rabin and Schrag (1999) investigated the impact of the confirmation bias on belief formation. They found that confirmation bias can lead to overconfidence which in-turn can prevent adequate learning (changing one's opinion or view in light of new information) even after receiving an infinite amount of contradictory information.

Bandwagoning/Convergence: This tendency, often referred to as the bandwagoning phenomenon, occurs when one agent performs an action after witnessing others undertake the same action. Redmond (2003) shows that adoption and diffusion (the spread of adoption thru a network) is a social process facilitated by the would-be adopters desire to emulate their peers. Hirshleifer and Teoh (2003) present a hierarchy of convergent herd behavior rom A - the lowest degree to D- the highest degree. Their argument is as follows:

A. Convergence/divergence: the observation of others can influence an agent's actions

B. Observational influence: the observation of others influences an agent's actions in an imperfect way

C. Rational observational learning: the observation of others influences an agent's actions in a predictable Bayesian manner

D. Informational cascades: the observation of others is so informative that convergence/herding/adaptation is the only rational result

As explained by Celen and Kariv (2004), the most notable difference between scenario A and D is fragility. A is fragile because the agents have simply converged on an action simultaneously which can be changed if new contradictory information arises. D, on the other hand is stable, meaning that the effect is so strong that new contradictory information will have no effect. An example of this difference is observing that your friend makes the same investment decision as you or that Warren Buffet makes that same decision ${ }^{1}$. Your friend's decision to make an investment doesn't necessarily indicate to you whether or not this investment is "good", so you may either interpret this positively and invest more or negatively and sell; if however you observe Warren Buffet undertake an investment you will feel almost compelled to follow suit if at all possible. Logically, religious affiliations should have a strong impact on the degree of convergence /adaptation because it has been shown that individuals act in accordance with social norms of their peers (Kohlberg, 1984) and align their beliefs with those of the local culture and religion (Schneider, 1987). Furthermore, we know that people have the tendency to self-select their peers by choosing to work and live in an area where the local culture and religious beliefs are "most suitable for them" (Cialdini and Goldstein, 2004) thus reinforcing this relationship. There is no reason to expect that financial decisions should be exempt from this phenomenon, in fact; Kumar et al. (2011) showed that religious characteristics which had spread among neighborhoods actually affected the portfolio characteristics of institutional investors.

When the "Shemita effect" was explained on The 700 Club it likely almost immediately fell into category D and was probably taken as "gospel" given the prominence of the show and its host. As Prechter (2001) explained "anyone who shares a prevailing majority opinion on any subject, particularly one that is intensely attended by the emotions of the limbic system (such as...religion...), is treated with the respect due his obvious intelligence and morality." If that were the case, it would have been almost impossible for any individual Evangelical to voice a dissenting opinion since to do so would result in cognitive and emotional discomfort (Sunstein, 1996), or in Prechter's words, "One who utters an opposing opinion is immediately punished by a chorus of deprecating smiles, cackling, mooing, snorting, nipping or outright hostility." No one would want that but, Norenzayan and Shariff (2008) suggest that followers of a religious sect may be even more susceptible because they tend to be highly sensitive towards their reputation within the group. They show that individuals adapt to the business practices that satisfy the religious tenets of their co-religionist

1I'm honestly not sure who to attribute this example to. I have used it several times in my classes but I'm not sure where or if it is published. 
peers (Norenzayan and Shariff, 2008). When viewed thru the lens of this research, the confirmation/convergence/bandwagoning phenomena is clear: once Cahn's theory (which appeared to be of good quality) was given credence by Pat Robertson (a decision maker with strong commitment towards the idea) his followers (who we assume for arguments sake are less confident in their understanding of market forces) felt compelled to "jump on board" with the idea, thus perpetuating it.

Has anything like this ever happened before? Strange as these events may seem, there are several examples of the consequences of these biases through history, most notably the "Tulip Mania bubble" of $17^{\text {th }}$ century Holland. Turkish traders introduced tulips to Holland in the early sixteenth century where they quickly became popular among the wealthy (Van der Veer, 2012). At first the market for tulips, particularly the rare varieties was composed almost entirely of wealthy well-informed merchants trading actual blooms. By 1634, however, a futures market had developed to facilitate sales throughout the year without the benefit of actually seeing the resulting flowers (Van der Veer, 2012). In addition to near continuous trading, this new market structure allowed traders to make a profit based purely on price fluctuations without having any knowledge of the underlying quality of the product (Goldgar, 2007). An informational cascade likely contributed the development of the speculative bubble. As Van der Veer (2012) notes, the traders were often linked to one another by religion, marriage, and/or profession, thus likely prompting them to assigned a greater weight to the decisions of other traders which, when aggregated across the entire market, came to outweigh the influence of private knowledge setting the cascade and eventual bubble in motion.

More recently, one may recall the panic surrounding "Y2K". Leading up to January 1, 2000 there were several media reports of a potential disasters resulting from computer programs whose software had been written with the year in two digit form (i.e.: 98 rather than 1998) assuming that January 1, 2000 was actually January $1^{\text {st }} 1900$ ! In the United States, President Bill Clinton appointed a "Y2K Czar" to insure that the military, financial and medical infrastructure of the country would survive the dawn of the new century while citizens stocked up on cash, canned goods, water and other supplies (Winerip, 2013). Philip \& Harpold (2002) explored the media culture that sprung up in the midst of the panic which they explain lead to the publication of a dozen novels and half a dozen major motion pictures and straight to video films all based on the consequences of this single computer-programming oversite! Even the Reverend Jerry Fallwell weighted in stating, "I believe that Y2K may be G-d's instrument to shake this nation, humble this nation, awaken this nation from this nation start a revival that spreads the face of the earth before the Rapture of the Church." While there were undoubtedly programs that needed updating, the panic that ensued also illustrates the impacts of confirmation and bandwagoning biases.

\section{Summary and Conclusion}

Many Evangelical Christians believe that America is a land of spiritual exceptionalism ordained by G-d for greatness and that economic downturns can arise as a consequence of the loss of G-d's favor; so when Johnathan Cahn proposed the "Shemita effect" which purportedly linked the country's economic success or failure to a predictable biblically ascribed cycle, it quickly circulated thru the community. Cahn and his contemporaries touted claims that the seven year Shemita cycle mirrored stock market patterns over the last 50 years suggesting that the market would collapse in mid-September, 2015. News of this cycle quickly circulated thru the Evangelical media and at least one man was convinced enough to start an entire investment company based on this theory. The outside observer is left scratching their head and asking why this theory persisted and spread thru the community since it is easily disproven via basic statistical analysis of freely available data. This entire episode is a textbook case of confirmation bias and bandwagoning!

The confirmation bias is the tendency for a person to place more weight on information that supports his/her opinion and to discount information that runs contrary to it. It is known to be strongest when the information received is of good quality and the individual has a strong commitment to the belief (Hart et al., 2009). Cahn's book was a best seller and the story was picked up by several Evangelical and mainstream news sites which undoubtedly helped to increase the appearance of its credibility. Also, the argument as presented appears to be plausible. Furthermore, Evangelical Christian theology has ascribed negative economic events to sin in the past so the belief was already in the collective psyche. For these reasons, the average Evangelical investor likely believed that the "Shemita effect" was true. The cumulative effect of these individual beliefs likely lead 
to a nearly inescapable informational cascade whereby any attempt to disprove the phenomena could produce consequences ranging from psychological discomfort to potential ostracism so the idea was perpetuated. This episode presents a clear precautionary tale for all investors, regardless of their faith: recognize your personal biases and the biases of your information sources. From a policy perspective, the continued occurrence of these events illustrates the need for competent financial advisors and/or legitimizes the call for increased investor protection regulation.

\section{References}

Berkowitz, A. E. (2015). Mathematician Looks to Bible to Predict Shmittah Market Trends. Breaking Israel News. 9/1/15 Retrieved from: http://www.breakingisraelnews.com/48068/shmittah-markettrends-point-to-really-bad-crash-in-september/\#dYPypf5BEGMeRLiw.99

Berwick, J. (2014). Shemitah Exposed: Financial Crisis Planned For September 2015, YouTube. Retrieved from: https://www.youtube.com/watch?v=rkELgi6EkNo

Carlson, E. (2015). The Stock Market Shemitah Cycle, The Market Oracle. Retrieved from: http://www.marketoracle.co.uk/Article52101.html

Çelen, B. \& Kariv, S. (2004). Distinguishing Informational Cascades from Herd Behavior in the Laboratory. American Economic Review, 94(3), 484-498

Cialdini, R. \& Goldstein, N. (2004). Social Influence: Compliance and Conformity. Annual Review of Psychology, $55,591-621$.

Darley, J. \& Gross, P. (1983). A hypothesis-confirming bias in labeling effects. Journal of Personality and Social Psychology, 44, 20-33.

Goldgar, A. (2007). Tulipmania: Money, Honor, and Knowledge in the Dutch Golden Age. London: University of Chicago Press.

Hart, W., Albarracin, D., Eagly, A. H., Brechan, I., Lindberg, M. J. \& Merrill, L. (2009). Feeling validated versus being correct: A meta-analysis of selective exposure to information. Psychological Bulletin, 135, 555588

Hirelman, M. (2015) Shemitah Investment Advisors LLC, Investment Strategy. Retrieved from: http://www.shemitahinvestmentadvisors.com/

Hirshleifer, D. \& Teoh, S. H. (2003). Herd Behaviour and Cascading in Capital Markets: A Review and Synthesis. European Financial Management, 9(1), 25-66.

Hohmann, L. (2015) U.S. Remains on Perilous Shemitah Course. Retrieved from: http://www.wnd.com/2015/06/u-s-remains-on-perilous-shemitah-course/

Hunter, J. D. (1991). Culture Wars: The Struggle to Define America. New York: Basic Books

Kohlberg, L. (1984). The Psychology of Moral Development: The Nature and Validity of Moral Stages. Essays on Moral Development. San Francisco: Harper \& Row

Krakowski, Y. (2014). Everything you need to know about Shemittah. Jewish Action, Orthodox Union, Fall, 2014.

Kuhnen, C. \& Knutson, B. (2011). The Influence of Affect on Beliefs, Preferences, and Financial Decisions. The Journal of Financial and Quantitative Analysis, 46(3), 605-626. Retrieved from http://www.jstor.org/stable/23018541

Kumar, A., Page, J. K. \& Spalt, O. G. (2011). Religious Beliefs, Gambling Attitudes, and Financial Market Outcomes. Journal of Financial Economics, 102(3), 671-708

Lord C., Ross, L. \& Lepper, M. (1979). Biased assimilation and attitude polarization: The effects of prior theories on subsequently considered evidence. Journal of Personality and Social Psychology, 37, 20982109.

Martin, S. A. (2013). Evangelical Economic Rhetoric: The Great Recession, the Free-Market and the Language of Personal Responsibility. Dissertation, University of California San Diego

Norenzayan, A. \& Shariff, A. (2008). The Origin and Evolution of Religious Prosociality. Science, 322, 5898, $58-62$.

Ohrenstein, R. A. (1998). Talmud and Talmudic tradition. a socio-economic perspective. Ancient and Medieval Economic Ideas and Concepts of Social Justice, New York: Brill, 209-68.

Philip, K. \& Harpold, T. (2002). Party Over, Oops, Out of Time: Y2K, Technological 'Risk'and Informational Millenarianism. 
Phillips-Fein, K. (2009). Invisible Hands: The Making of the Conservative Movement from the New Deal to Reagan. New York: W.W. Norton \& Co.

Prechter Jr, R. R. (2001). Unconscious herding behavior as the psychological basis of financial market trends and patterns. The Journal of Psychology and Financial Markets, 2(3), 120-125.

Rabin, M. \& Schrag, J. (1999). First impressions matter: A model of confirmatory bias. Quarterly Journal of Economics, 114, 37-82.

Redmond, W. (2003). Innovation, Diffusion, and Institutional Change. Journal of Economic Issues, 37(3), 665679.

Robertson, P. (2015). Jonathan Cahn and The Present Shemitah, The 700 Club. 9/8/2015. Retrieved from: http://www.cbn.com/tv/4470998689001

Schneider, B. (1987). The People Make the Place. Personnel Psychology, 40(3), 437-453.

Schwartz, E. (2014). HeterMechira, Rabbi Isaac Elchanan Theological Seminary, The Benjamin and Rose Berger CJF Torah To-Go Series

Schwimmer, L. (2015). The Biblical Prophecy of the Shemitah Jewish New Year \& What it Means to America, Huffington Post 10/1/15.

Sinha, P. (2015). Shemitah, end of Jewish calendar cycle, spooks markets. The Times of India. [Mumbai] $8 / 27 / 15$.

Skillen, J. (2004). In Pursuit of Justice: Christian-Democratic Explorations. Rowman and Littlefield

Stahl, J. (2015). Bible Commandment Marks End of Shemitah, CBN news. 10/1/15

Sunstein, C. R. (1996). Social norms and social roles. Columbia law review, 96(4), 903-968.

Synder, M. (2015). 10 Things That Are Going to Happen Within 15 Days of the End of the Shemitah, Charisma News, http://www.charismanews.com/opinion/51107-10-things-that-are-going-to-happen-within15-days-of-the-end-of-the-shemitah

The Concise Oxford Dictionary. Oxford University Press. 1978.

Van der Veer, A. M. (2012). The Dutch Tulip Mania: The Social Foundations of a Financial Bubble. Department of Government College of William \& Mary.

Weber, M. (1905). The Protestant Ethic and the Spirit of Capitalism. London: Unwin Hyman

Wilshire 5000 Total market Index Fact Sheet. 6/30/15 retrieved from: https://www.wilshire.com/indexinfo/pdf/Wilshire\%205000/Wilshire\%205000\%20Fact\%20Sheet. pdf.

Winerip, M. (2013). Revisiting Y2K: Much Ado About Nothing? Retrieved from: http://www.nytimes.com/2013/05/27/booming/revisiting-y2k-much-ado-about-nothing.html

Zenz, A. (2015). An Empirical, Statistical and Exegetical Evaluation of the Shemita Effect Suggested by Johnathan Cahn. Working Paper- European School of Culture and Theology.

Zweig, J. (2009). How to Ignore the Yes-Man in Your Head. The Wall Street Journal, 11(9). 